\title{
Hyperosmolar hyperglycaemic state (HHS) as the first manifestation of type 2 diabetes in a child
}

\author{
Stan hiperglikemiczno-hipermolalny jako pierwsza manifestacja cukrzycy typu 2 u dziecka
}

\author{
Agnieszka Zubkiewicz-Kucharska, Joanna Chrzanowska, Anna Noczyńska
}

Department of Endocrinology and Diabetology for Children and Adolescents, Wrocław Medical University, Poland

\begin{abstract}
Hyperglycaemic hyperosmolar state (HHS) may occur in young patients with type 1 and type 2 diabetes and in infants with hyperglycaemia. Hyperglycaemic hyperosmolar state is characterised by extremely high glucose concentration, which, by increasing osmotic diuresis, intensifies dehydration. Hyperglycaemic hyperosmolar state criteria include the following: plasma glucose $>600 \mathrm{mg} / \mathrm{dl}$, venous $\mathrm{pH}>7.25$, sodium bicarbonate $>15 \mathrm{mmol} / \mathrm{l}$, slight ketonuria, plasma osmolality $>320 \mathrm{mOsm} / \mathrm{kg}$, and impairment of consciousness (aggression, unconsciousness, convulsions). We describe the case of a 13-year-old patient with severe obesity (at presentation body mass $>120 \mathrm{~kg}, \mathrm{BMI}>40 \mathrm{~kg} / \mathrm{m}^{2}$ ), who developed HHS (glycaemia $647 \mathrm{mg} / \mathrm{dl}, \mathrm{pH} 7.18, \mathrm{pCO}_{2} 96.5 \mathrm{mmHg}, \mathrm{BE}-5.0 \mathrm{mmol} / \mathrm{l}, \mathrm{HCO}$ $35.2 \mathrm{mmol} / \mathrm{l}$; $\mathrm{Na} 167 \mathrm{mmol} / \mathrm{l}$, plasma osmolarity $370 \mathrm{mOsm} / \mathrm{kg}$ ) in the course of pneumonia and newly diagnosed type 2 diabetes $\left(\mathrm{HbA}_{1 \mathrm{c}} 15.5 \%\right.$, C-peptide $\left.2.63 \mathrm{ng} / \mathrm{ml}\right)$. In the follow-up, due to the hypoglycaemia, insulin was discontinued, metformin was administered at a dose of $2 \mathrm{~g} /$ day, with a further reduction to $500 \mathrm{mg} /$ day, together with physical rehabilitation and a low-calorie diet. Weight reduction during 6 months of observation was approximately $37 \mathrm{~kg}$. Due to breathing disorders occurring at night, the girl still needs breathing assistance (CPAP).
\end{abstract}

Key words:

hyperglycaemic hyperosmolar state, type 2 diabetes, obesity.

\section{Streszczenie}

Stan hiperglikemiczno-hiperosmolarny (HHS) może wystąpić u młodocianych pacjentów z cukrzycą typu 1 i 2 oraz u niemowląt z hiperglikemią. Charakteryzuje się wyjątkowo dużymi stężeniami glukozy, które poprzez zwiększenie diurezy osmotycznej nasilają odwodnienie. Kryteria HHS obejmują: stężenie glukozy w osoczu > $600 \mathrm{mg} / \mathrm{dl}$, pH krwi żylnej > 7,25, stężenie wodorowęglanu sodu $>15 \mathrm{mmol} / \mathrm{l}$, brak ketonurii lub niewielką ketonurię, osmolalność w osoczu > $320 \mathrm{mOsm} / \mathrm{kgH}_{2} \mathrm{O}$, zaburzenia świadomości (agresja, utrata przytomności, drgawki). W pracy opisano przypadek 13-letniej pacjentki z ciężką otyłością (m.c. $\left.>120 \mathrm{~kg}, \mathrm{BMI}>40 \mathrm{~kg} / \mathrm{m}^{2}\right)$, u której rozwinął się HHS (glikemia 647 mg/dl, pH 7,18, pCO 96,5mm Hg, BE - 5,0 mmol/l, HCO 35,2 mmol/l, Na 167 mmol/l, osmolarność osocza $370 \mathrm{mOsm} / \mathrm{kg})$ w przebiegu zapalenia płuc i nowo zdiagnozowanej cukrzycy typu 2 (HbA $15,5 \%$, peptyd C $2,63 \mathrm{ng} / \mathrm{ml}$ ). W czasie leczenia wycofano się z insulinoterapii z powodu hipoglikemii, natomiast metforminę podawano początkowo w dawce $2 \mathrm{~g} /$ dobę, z dalszą redukcją do $500 \mathrm{mg} /$ dobę, podjęto rehabilitację ruchową oraz utrzymywano dietę z ograniczeniem podaży kalorii. Zmniejszenie masy ciała podczas 6-miesięcznej obserwacji wynosiło około $37 \mathrm{~kg}$. Z powodu zaburzeń oddychania występujących w nocy dziewczynka nadal potrzebuje wsparcia oddechowego (CPAP).

\section{Słowa kluczowe:}

stan hiperglikemiczno-hipermolalny, cukrzyca typu 2, otyłość. 
The life-threatening hyperglycaemic hyperosmolar state $(\mathrm{HHS})$ is characterised by very high glycaemia and hyperosmolality, with little or no acidosis. This is due to slowly increasing insulin deficiency, which is insufficient to cover the demand. Among the many possible reasons for the development of HHS, the most common are infections. Others include the use of certain drugs and psychoactive substances, non-compliance with therapy, and co-morbid diseases [1]. Hyperglycaemic-hyperosmolar state is believed to occur in approximately $1 \%$ of patients hospitalised for diabetes [2]. Most cases concern older people with type 2 diabetes. In the developmental population, HHS develops usually in the course of type 2 diabetes, but it can also occur in type 1 diabetes. It is believed to be associated with a delay in the diagnosis of these diseases. Mortality

Table I. Selection of initial laboratory test results

\begin{tabular}{lll}
\hline & Results & Normal range \\
\hline hsCRP & $97 \mathrm{ng} / \mathrm{ml}$ & $0-5$ \\
\hline procalcitonin & $1.97 \mathrm{ng} / \mathrm{ml}$ & $0-0.1$ \\
\hline $\mathrm{Na}$ & $167 \mathrm{mmol} / \mathrm{l}$ & $135-145$ \\
\hline $\mathrm{K}$ & $4.2 \mathrm{mmol} / \mathrm{l}$ & $3.8-5.0$ \\
\hline $\mathrm{Cl}$ & $112 \mathrm{mmol} / \mathrm{l}$ & $98-107$ \\
\hline Mg & $2.98 \mathrm{mg} / \mathrm{dl}$ & $1.7-2.2$ \\
\hline phosphate & $0.7 \mathrm{mg} / \mathrm{dl}$ & $4.5-5.5$ \\
\hline Ca & $8.5 \mathrm{mg} / \mathrm{dl}$ & $8.4-10.2$ \\
\hline glucose & $647 \mathrm{mg} / \mathrm{dl}$ & \\
\hline HbA & $15.5 \%$ & $5.4-6.2$ \\
\hline ALAT & $97 \mathrm{U} / \mathrm{l}$ & $0-55$ \\
\hline ASPAT & $200 \mathrm{U} / \mathrm{l}$ & $5-34$ \\
\hline LDH & $602 \mathrm{U} / \mathrm{l}$ & $22-80$ \\
\hline INR & 1.2 & $0.9-1.3$ \\
\hline total bilirubin & $1.1 \mathrm{mg} / \mathrm{dl}$ & $0.2-1.2$ \\
\hline serum amylase & $558 \mathrm{U} / \mathrm{l}$ & $22-80$ \\
\hline lipase & $4701 \mathrm{U} / \mathrm{l}$ & $7-60$ \\
\hline creatine kinase & $313 \mathrm{U} / \mathrm{l}$ & $29-168$ \\
\hline serum creatinine & $2.1 \mathrm{mg} / \mathrm{dl}$ & $0.57-1.11$ \\
\hline total cholesterol & $72 \mathrm{mg} / \mathrm{dl}$ & $<190$ \\
\hline HDL cholesterol & $7 \mathrm{dl}$ & \\
\hline
\end{tabular}

in the course of $\mathrm{HHS}$ reaches $20-30 \%$, and it is approximately 10-times higher than in diabetic ketoacidosis (DKA) [3, 4].

The clinical picture of HHS is dominated by significant dehydration and dyselectrolitaemia, gradually increasing polyuria, and polydipsia. Loss of fluid in the course of this syndrome is even twice as high as in DKA. The assessment of hydration of patients is hampered by obesity and hyperosmolality. In addition, hypernatraemia and hypertonicity prevent reduction of intravascular fluid volume, so the symptoms of dehydration are less visible. Preservation of circulatory efficiency happens at the expense of reducing intracellular space, which is particularly expressed within the central nervous system. The severity of the disturbances of consciousness may vary from lethargy to coma [1, 2].

The criteria for HHS include:

- plasma glucose concentration > $600 \mathrm{mg} / \mathrm{dl}$ (33.3 mmol/l),

- arterial $\mathrm{pH}>7.30$; venous $\mathrm{pH}>7.25$,

- serum bicarbonate $>15 \mathrm{mmol} / \mathrm{l}$,

- small ketonuria, absent or small ketonaemia,

- effective serum osmolality > $320 \mathrm{mOsm} / \mathrm{kg}$,

- change in consciousness (e.g. limited obtundation, combativeness) or seizures,

- significant dehydration.

We present a case of a teenager in whom the HHS was the first manifestation of type 2 diabetes, to underline the importance of early diagnosis and appropriate treatment of hyperglycaemic crisis in severely dehydrated children.

\section{Case report}

A 13-year-old girl with severe obesity (> $120 \mathrm{~kg}, 165.5 \mathrm{~cm}$ height, $\mathrm{BMI}>40 \mathrm{~kg} / \mathrm{m}^{2}$ ) was admitted to the district hospital in severe condition, with increased dyspnoea and consciousness disorders. In the physical examination considerable respiratory effort, numerous crackling over the lungs, tachycardia of 130 beats/min, tense abdomen and abdominal pain, enlarged liver, slight dehydration features, and elevated blood pressure of $140 / 90 \mathrm{~mm} \mathrm{Hg}$ were found.

It was known that antibiotic therapy had been conducted for a week due to pneumonia with elevated body temperature; however, no significant improvement was observed. The parents reported that there had been incidents of involuntary daytime and night-time urination recently. Excessive weight gain in the child was observed from five years of age. Family history was not relevant, and parents and younger sister were healthy, with proper body mass.

In the additional tests performed, hyperglycaemia was found to be $647 \mathrm{mg} / \mathrm{dl}$, acidosis $\mathrm{pH} 7.18, \mathrm{pCO}_{2} 96.5 \mathrm{~mm} \mathrm{Hg}$, $\mathrm{pO}_{2} 43.2 \mathrm{~mm} \mathrm{Hg}, \mathrm{BE} 5.0 \mathrm{mmol} / \mathrm{l}$, and $\mathrm{HCO}_{3} 35.2 \mathrm{mmol} / \mathrm{l}$. The sodium concentration was $167 \mathrm{mmol} / \mathrm{l}$ (corrected $\mathrm{Na} 178 \mathrm{mmol} / \mathrm{l}$ ), and the serum osmolarity was $370 \mathrm{mOsm} / \mathrm{kg} \mathrm{H}_{2} \mathrm{O}$. Ketonuria was not found.

Due to the deteriorating condition of the child and respiratory failure, the girl was referred for further treatment in the paediatric intensive care unit (PICU). The patient required mechanical ventilation. 
On admission to the PICU, dehydration was found, auscultatory phenomena characteristic of pneumonia, and abdominal pain. The results of selected additional tests are given in Table I.

In urinalysis, no ketonuria or glucosuria were confirmed. However, in the following days of treatment, in diurnal urine (5280 l) $0.37 \mathrm{~g} /$ day of glucose and proteinuria (1.32 g/day) were found.

In imaging studies, pneumonia was confirmed in chest X-ray (slight inflammatory lesions and/or small amounts of diffuse fluid in the left pleural cavity), abdominal CT revealed liver steatosis and pancreatitis, whereas in MR of the brain numerous ischaemic changes and microcortures in the area of the temporo-parietal-occipital cortex were described.

In the girl the diagnosis of diabetes, most probably of type 2, was confirmed, complicated by HHS in the course of pneumonia, acute respiratory failure, and acute pancreatitis.

Noteworthy was the significant dyselectrolitaemia, definitely more extreme than usually found in ketoacidosis. The severe hypophosphatemia present in the patient could have led to rhabdomyolysis, which was manifested by increased CK activity (a further increase in CK activity to $1280 \mathrm{U} / \mathrm{I}$ was observed in the control examination).

Despite intensive insulin therapy and fluid therapy (on the first day $7100 \mathrm{ml}$, a furosemide-assisted diuresis - $4764 \mathrm{ml}$, fluid balance $+1540 \mathrm{ml}$ ), in the first days of treatment the blood glucose levels were not normalised, patient was dehydrated, and heavy electrolyte disturbances were still present.

Moreover, antibiotic therapy was maintained. Due to the central venepuncture used and the risk of thrombosis, the girl received anticoagulant therapy. Because mechanical ventilation was used, she received sedation. In addition, due to anae- mia, a transfusion of two units of red cell concentration (RCC) was made.

The patient was extubated on the $14^{\text {th }}$ day of hospitalisation. After adjustment of ionic disturbances, glycaemia, and hydration, subcutaneous insulin therapy was implemented. There was also a gradual decline in insulin demand observed. Physical rehabilitation was started.

In the $20^{\text {th }}$ day, the girl was transferred to our Department. Due to the numerous episodes of hypoglycaemia, insulin was discontinued while metformin was administered at a dose of $2 \mathrm{~g} /$ day. Physical rehabilitation was continued and her diet was maintained with limited caloric intake (1500 kcal/day). During the hospitalisation in our Department, normalisation of transaminases, amylase, and lipase activity as well as CRP were observed. The significantly lower percentage of $\mathrm{HbA}_{1 \mathrm{c}}(9.9 \%)$ resulted not only from near-normoglycaemia maintained during long hospitalisation, but also from the transfusion of RCC. In addition, the high concentration of C-peptide $4.23 \mathrm{ng} / \mathrm{ml}[\mathrm{N}$ : 0.9-7.1] and the undetectable titre of antibodies against pancreatic islets' antigens (ICA, GAD, IA2) confirmed the diagnosis of type 2 diabetes.

The girl was discharged home in good condition after 28 days of treatment. At that time, she reduced her body mass by approximately $13 \mathrm{~kg}$ (including about $10 \mathrm{~kg}$ during her stay in PICU and about $3 \mathrm{~kg}$ in our Department). Figure 1 presents the assessment of body mass composition by bioimpedance method performed on the day of discharge.

Implemented intensive behavioural treatment resulted in reduction of body mass by $37 \mathrm{~kg}$ in seven months. The transaminase and CK activity normalised. The metabolic control of diabetes is optimal $\left(\mathrm{HbA}_{1 \mathrm{c}} 5.7 \%\right)$. The results of the assessment of body composition made during subsequent visits are
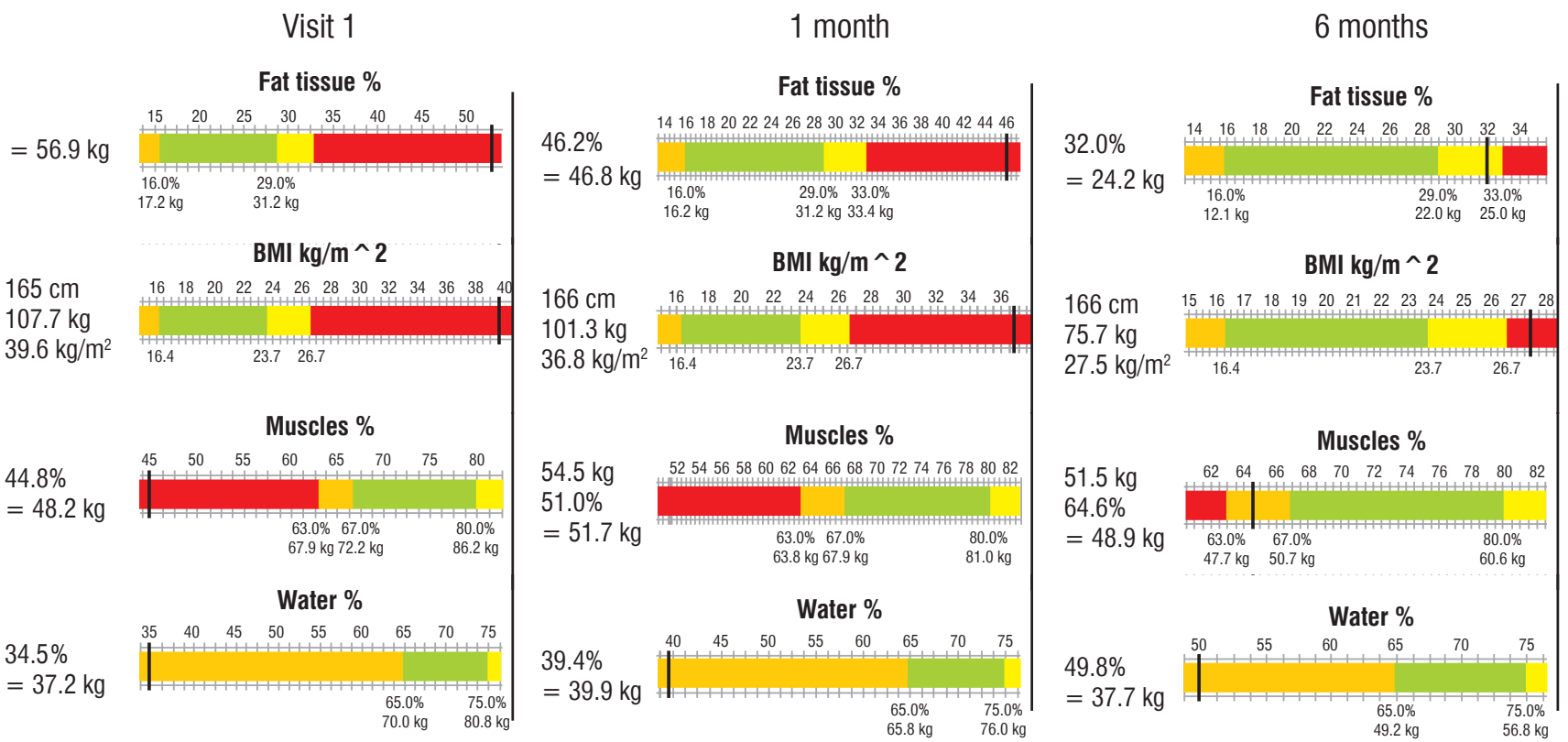

Figure 1. Body mass composition of the presented patient 
presented in Figure 1. Due to breathing disorders occurring at night, the girl still needs breathing assistance (CPAP). The dose of metformin was reduced to $500 \mathrm{mg} /$ day.

\section{Discussion}

Hyperosmolar hyperglycaemic state is a life-threatening condition manifested by marked elevation of blood glucose and hyperosmolality with little or no ketosis. Undiagnosed diabetes mellitus, most often type 2 , with underlying infection is the most common cause of HHS, as it was in the presented case [1]. It is, however, still an unusual presentation of type 2 diabetes in children, found in $2 \%$ of cases, developing due to diagnosis delay, which also occurred in our patient [3-5]. Recent studies showed an increase of $\mathrm{HHS}$ prevalence in the paediatric population [6, 7]; it is therefore important to know how to diagnose and treat this condition.

According to ISPAD [1], the diagnostic criteria for HHS include the following: severe hyperglycaemia, which, together with hypernatraemia, results in hyperosmolality, near-normal $\mathrm{pH}$ with normal concentration of bicarbonates, as well as no ketonuria and mild ketonaemia. Altered consciousness or seizures are present in approximately $50 \%$ of cases.

The presented patient fulfilled most of the diagnostic criteria; however, a mild acidosis was stated with no ketonuria ( $\mathrm{pH} 7.18)$. It was probably due to severe dehydration followed by hypoperfusion and lactic acidosis. Water deficit of approximately 100-200 $\mathrm{ml} / \mathrm{kg}$ results of the massive losses due to the osmotic diuresis. In adult patients fluid deficiencies can reach over $12 \mathrm{li}$ tres $[8,9]$. The fluid therapy conducted in our patients was intensive from the beginning - during the opening 24 hours of the treatment over seven litres of fluids were administrated; however, fluid homeostasis was not achieved in the first few days. Moreover, creatinine and urea concentrations were elevated, all of which indicates severe dehydration.

As for severe dehydration occurring in all patients with $\mathrm{HHS}$, fluid therapy seems to be most important, in order to expand the intra and extravascular volume and to restore normal renal perfusion. However, dehydration should be corrected gradually, to slowly reduce the serum sodium concentration (not more than $0.5 \mathrm{mmol} / \mathrm{l} / \mathrm{h}$ ) and serum osmolality (not more than $3 \mathrm{mOsm} / \mathrm{kg} \mathrm{H}_{2} \mathrm{O} / \mathrm{h}$ ). It is recommended that hypotonic fluids be administered until normal serum osmolality is reached, followed by a physiological saline. In the case of inadequate perfusion and haemodynamic insufficiency, infusion of isotonic $\mathrm{NaCl}$ is advised because isotonic fluids maintain the intravascular volume more effectively $[1,8,9]$.

Correction of dehydration and hyperosmolality results in the decrease of blood glucose concentration. It is recommended to begin insulin administration at a dose of 0.025 to $0.05 \mathrm{U} / \mathrm{kg} / \mathrm{h}$ once plasma glucose has reduced to less than $50 \mathrm{mg} / \mathrm{dL}$ (3 mmol/l) per hour with fluid alone. This should maintain the decline in blood glucose concentration by 50-75 mg/dl/h (3-4.5 mmol///h). In patients with more severe ketosis and acidosis, insulin therapy should be started earlier [1, 9].
In HHS severe electrolyte deficits are observed, particularly potassium, phosphate, and magnesium. They are considered to be more extreme than in diabetic ketoacidosis, so adequate replacement therapy should be initiated. Potassium supplementation should be started even if potassium concentrations are within the normal range and when normal renal function is established [10]. Electrolyte imbalance was observed in our patient, with severe depletion of phosphates. Severe hypophosphataemia may lead to rhabdomyolysis, and paralysis is an important predictor of the DKA-associated mortality [11]. It is recommended that hypophosphataemia is treated; however, one should be aware that such therapy may contribute to hypocalcaemia. Intravenous solutions of a $50: 50$ mixture of potassium phosphate and potassium chloride are used, resulting in adequate phosphate supplementation with low risk of clinically significant hypocalcaemia [10]. Also, large deficits of magnesium occur in HHS patients. Hypomagnesaemia may contribute to hypocalcaemia during therapy; therefore, supplementation should be considered in patients with hypomagnesaemia and hypocalcaemia (25 to $50 \mathrm{mg} / \mathrm{kg}$ of magnesium per dose, three to four doses given every four to six hours, with a maximum infusion rate of $150 \mathrm{mg} / \mathrm{min}$ and $2 \mathrm{~g} / \mathrm{h}$ ) [10].

Other complications of dyselectrolitaemia include thrombosis and haemolytic anaemia [10], which occurred also in the presented patient.

As in DKA, bicarbonates are contraindicated because they elevate the risk of hypokalaemia as well as reduce the oxygen supply to tissues [1].

It was unexpected to find only diminutive glucosuria in our patient because urinary glucose excretion (UGE) is supposed to increase with the rise in blood glucose level in a proportional manner. However, one must remember that insulin receptor is present in renal tubular cells, and insulin stimulates sodium reabsorption in renal proximal tubules. Thus, the renal threshold for glucose reabsorption is higher in individuals with type 2 diabetes mellitus because of the enhanced sodium-glucose cotransporter 2 (SGLT2) expression in the course of hyperinsulinaemia and insulin resistance; this was demonstrated in a recent study by Chen et al. in patients with prediabetes and newly diagnosed type 2 diabetes, where insulin levels and insulin resistance were negatively associated with UGE, independent of blood glucose [12]. Reduction in UGE may contribute to the progression of hyperglycaemia. Moreover, severe hypovolaemia is observed in HHS, which leads to a progressive decline in glomerular filtration rate and may affect reabsorption of different substances in renal tubules.

In contrast to adult patients, in whom comorbidities play a role in HHS development, in the paediatric population HHS appears to occur most often in obese but otherwise healthy children and adolescents, with type 2 diabetes diagnosed at HHS presentation. Therefore, HHS in the paediatric population may be considered as a consequence of severe obesity. Hence, with the increasing prevalence of obesity in children and adolescents, an increase in paediatric HHS frequency should be expected. As such, increased awareness of the occurrence of this life-threatening condition and its treatment is essential. 


\section{References}

1. Wolfsdorf Jl, Glaser N, Agus M, et al. Diabetic Ketoacidosis and Hyperglycemic Hyperosmolar State: A Consensus Statement from the International Society for Pediatric and Adolescent Diabetes. Pediatr Diabetes 2018; doi: 10.1111/pedi.12701.

2. Pasquel FJ, Umpierrez GE. Hyperosmolar hyperglycemic state: a historic review of the clinical presentation, diagnosis, and treatment. Diabetes Care 2014; 37: 3124-3131. doi: 10.2337/dc14-0984

3. Cho YM, Park BS, Kang MJ. A case report of hyperosmolar hyperglycemic state in a 7-year-old child: An unusual presentation of first appearance of type 1 diabetes mellitus. Medicine (Baltimore). 2017; 96: e7369. doi: 10.1097/MD.0000000000007369;

4. Price A, Losek J, Jackson B. Hyperglycaemic hyperosmolar syndrome in children: Patient characteristics, diagnostic delays and associated complications. J Paediatr Child Health 2016; 52: 80-84. doi: 10.1111/jpc. 12980

5. Klingensmith GJ, Connor CG, Ruedy KJ, et al. Presentation of youth with type 2 diabetes in the Pediatric Diabetes Consortium. Pediatr Diabetes 2016; 17: 266-273.

6. Rosenbloom AL. Hyperglycemic hyperosmolar state: an emerging pediatric problem. J Pediatr 2010; 156: 180-184.

7. Fourtner SH, Weinzimer SA, Levitt Katz LE. Hyperglycemic hyperosmolar non-ketotic syndrome in children with type 2 diabetes. Pediatr Diabetes 2005; 6: 129-135.
8. Baldrighi M, Sainaghi PP, Bellan M, et al. Hyperglycemic Hyperosmolar State: A Pragmatic Approach to Properly Manage Sodium Derangements. Curr Diabetes Rev 2018; 14: 534-541. doi: 10.217 4/1573399814666180320091451.

9. Rozpoznawanie i leczenie ostrych powikłań cukrzycy. W: Wierusz-Wysocka B, Zozulińska-Ziółkiewicz D. Postępowanie w stanach nagłych i szczególnych u chorych na cukrzycę. Via Medica, Gdańsk 2010.

10. Zeitler P, Haqq A, Rosenbloom A, Glaser N; Drugs and Therapeutics Committee of the Lawson Wilkins Pediatric Endocrine Society. Hyperglycemic hyperosmolar syndrome in children: pathophysiological considerations and suggested guidelines for treatment. J Pediatr 2011; 158: 9-14. doi: 10.1016/j.jpeds.2010.09.048

11. Agarwal A, Yadav A, Gutch M, et al. Prognostic Factors in Patients Hospitalized with Diabetic Ketoacidosis. Endocrinol Metab (Seoul) 2016; 31: 424-432. doi: 10.3803/EnM.2016.31.3.424

12. Chen J, Qiu SH, Guo HJ, et al. Associations of Insulin Levels and Insulin Resistance With Urine Glucose Excretion Independent of Blood Glucose in Chinese Adults With Prediabetes and Newly Diagnosed Diabetes. Front Physiol 2018; 9: 1666. doi: 10.3389/ fphys.2018.01666 